\title{
KEDUDUKAN TIM PENGAWAL DAN PENGAMANAN PEMERINTAHAN DAN PEMBANGUNAN DAERAH (TP4D) DALAM RANGKA UPAYA PENCEGAHAN TINDAK PIDANA KORUPSI
}

\author{
Muhammad Junaidi \\ Marthin \\ Kejaksaaan Negeri Tarakan \\ Zabran4710@gmail.com
}

\begin{abstract}
ABSTRAK
Penelitian ini dilatarbelakangi oleh Kejaksaan Republik Indonesia yang telah membentuk struktur organisasi baru yaitu Tim Pengawal dan Pengamanan Pemerintahan dan Pembangunan atau dikenal dengan nama (TP4). TP4 ini berlokasi di pusat (Kejaksaan Agung) dan ditiap-tiap daerah (Kejaksaan Tinggi dan Kejaksaan Negeri). Kelahiran TP4 mulanya untuk meningkatkan peran Kejaksaan dibidang perdata dan tata usaha negara (DATUN) tetapi pada akhirnya berada di bidang Intelijen. Selain itu, pembentukan TP4 merupakan salah satu respon Kejaksaan adanya Instruksi Presiden No. 7 Tahun 2015 Tentang Aksi Pencegahan dan Pemberantasan Korupsi tahun 2015. Pembentukan tim TP4 bertujuan untuk mengawal dan mengawasi pembangunan di daerah serta mendukung keberhasilan pemerintahan dan pembangunan melalui upaya upaya pencegahan secara preventif dan persuasif. Kejaksaan sesuai ketentuan Undang-undang Nomor 16 Tahun 2004 tentang Kejaksaan memiliki wewenang untuk melakukan penuntutan dan juga dapat bertugas sebagai penyidik untuk perkara tertentu sesuai dengan peraturan perundangan. Dalam penanganan perkara terdakwa tindak pidana korupsi, kejaksaan memiliki wewenang untuk melakukan penyidikan. Dalam pelaksanaannya tim TP4D banyak kemungkinan akan dihadapkan situasi rawan Penyimpanganpenyimpangan dan indikasi terjadinya tindak pidana korupsi terhadap proyek Pembagunan yang sedang dikawal, untuk menghindari hal tersebut sehingga Tim TP4D diharapkan mampu bekerja secara profesional. Selain itu, pembentukan TP4D, juga diharapkan dapat memaksimalkan daya serap anggaran Pembangunan kurang dikarenakan Pemerintah ketakutan untuk melaksanakan pembangunan, sehingga dengan adanya Tim TP4D pemerintah tidak ragu untuk melaksanakan pembangunan.
\end{abstract}

Kata Kunci: TP4D, Pembangunan dan Tindak Pidana Korupsi 


\begin{abstract}
This research was motivated by the Attorney General of the Republic of Indonesia which has formed a new organizational structure, namely Tim Pengawal dan Pengamanan Pemerintahan dan Pembangunan, also known as (TP4). These TP4s are located in the center (Attorney General's Office) and in each region (High Prosecutor's Office and Public Prosecutor's Office). The birth of TP4 was originally to increase the role of the Prosecutor in the civil and state administration (DATUN) but ultimately was in the field of Intelligence. In addition, the formation of TP4 was one of the attorneys' responses to the Presidential Instruction No. 7 of 2015 concerning the Action on the Prevention and Eradication of Corruption in 2015. The formation of the TP4 team aims to guard and supervise development in the region and support the success of government and development through preventive and persuasive prevention efforts. Prosecutors in accordance with the provisions of Law Number 16 of 2004 concerning the Prosecutor's Office have the authority to prosecute and can also serve as investigators for certain cases in accordance with laws and regulations. In handling cases of accused of corruption, the prosecutor's office has the authority to carry out investigations. In its implementation, the TP4D team is likely to be faced with situations prone to irregularities and indications of corruption in the development project being escorted, to avoid this so that the TP4D Team is expected to be able to work professionally. In addition, the formation of TP4D was also expected to maximize the absorption capacity of the development budget due to the Government's fear of implementing development, so that with the presence of the TP4D Team the government did not hesitate to carry out development.
\end{abstract}

Keywords: TP4D, Development and Corruption Crime 


\section{PENDAHULUAN}

Pada saat ini pemberantasan tindak pidana korupsi dilaksanakan oleh berbagai institusi seperti Kejaksaan, Kepolisian dan Komisi Pemberantasan Korupsi, oleh karena itu pengaturan kewenangan dalam hal pemberantasan tindak pidana korupsi yang diatur dalam Undang-Undang harus dilakukan secara berhatihati agar tidak terjadi tumpang tindih kewenangan dengan berbagai instansi tersebut.

Dalam sistem peradilan pidana peranan Kejaksaan sangat sentral karena Kejaksaan merupakan lembaga yang menentukan apakah seorang harus diperiksa oleh Pengadilan atau tidak. Jaksa pula yang menentukan apakah seorang akan dijatuhi hukuman atau tidak melalui kualitas surat dakwaan dan tuntutan yang dibuat. Sedemkian pentingnya posisi jaksa bagi proses penegakan hukum sehingga lembaga ini harus diisi oleh orang-orang yang profesional dan memiliki integritas tinggi.

Kejaksaan sebagai lembaga penegak hukum telah melakukan langkahlangkah nyata demi mencegah segala potensi-potensi sebagai yang diuraikan diatas. Kejaksaan melalui tugas pokok dan fungsi yang ada telah membentuk struktur organisasi baru yaitu Tim Pengawal dan Pengamanan Pemerintahan dan Pembangunan atau dikenal dengan nama (TP4). TP4 ini berlokasi di pusat (Kejaksaan Agung) dan ditiap-tiap daerah ( Kejaksaan Tinggi dan Kejaksaan Negeri). Kelahiran TP4 mulanya untuk meningkatkan peran Kejaksaan dibidang perdata dan tata usaha negara (datun). Selain itu, pembentukan TP4 merupakan salah satu respon Kejaksaan adanya Instruksi Presiden No. 7 Tahun 2015 Tentang Aksi Pencegahan dan Pemberantasan Korupsi tahun 2015.

Terbentuknya TP4/TP4D nantinya berkontribusi menghilangkan atau mengurangi pula tentang keraguan dan ketakutan dari stakeholder's atau dalam hal ini pemerintah beserta perangkatnya dalam menggunakan anggaran alokasi daerah untuk pembangunan. Sebab, jika salah mengambil kebijakan, tindakan mereka dapat diindikasikan ke dalam tindak pidana korupsi. TP4/TP4D juga sebagai cerminan bahwa Kejaksaan juga bisa untuk berkontribusi pada keberhasilan pembangunan yang pada akhirnya rakyat menjadi sejahtera.

Sejalan dengan Instruksi Presiden nomor 7 Tahun 2015 tentang aksi pencegahan dan pemberantasan korupsi yang untuk mendukung keberhasilan penyelengaraan pemerintahan dan pembangunan nasional maupun daerah, dalam melaksanakan tugas dan fungsi tim TP4 diatur di dalam Peraturan Jaksa Agung Nomor: PER-014/A/JA/11/2016 tentang mekanisme kerja teknis dan 
administrasi Tim Pengawal dan Pengaman dan Pemerintahan dan Pembangunan, sebagai tim yang dibentuk dalam mencegah terjadinya Tindak Pidana Korupsi dalam pelaksanaan Proyek- proyek Pembangunanan strategis Nasional.

Pembentukan tim TP4 bertujuan untuk mengawal dan mengawasi pembangunan di daerah serta mendukung keberhasilan pemerintahan dan pembangunan melalui upaya upaya pencegahan secara preventif dan persuasif. Kejaksaan sesuai ketentuan Undang-undang Nomor 16 Tahun 2004 tentang Kejaksaan memiliki wewenang untuk melakukan penuntutan dan juga dapat bertugas sebagai penyidik untuk perkara tertentu sesuai dengan peraturan perundangan. Dalam penanganan perkara terdakwa tindak pidana korupsi, kejaksaan memiliki wewenang untuk melakukan penyidikan. Dalam pelaksanaannya tim TP4D banyak kemungkinan akan dihadapkan situasi rawan Penyimpangan- penyimpangan dan indikasi terjadinya tindak pidana korupsi terhadap proyek Pembagunan yang sedang dikawal, untuk menghindari hal tersebut sehingga Tim TP4D diharapkan mampu bekerja secara profesional. Selain itu, pembentukan TP4D, juga diharapkan dapat memaksimalkan daya serap anggaran Pembangunan kurang dikarenakan Pemerintah ketakutan untuk melaksanakan pembangunan, sehingga dengan adanya Tim TP4D pemerintah tidak ragu untuk melaksanakan pembangunan.

\section{METODE PENELITIAN}

Penelitian ini merupakan penelitian hukum normatif dengan pendekatan masalah berbasis pendekatan perundang-undangan dan konseptual. Sumber bahan hukum yang dianalisis adalah bahan hukum primer dan sekunder. Bahan hukum primer yang dimaksud antara lain: Undang-undang Dasar Negara Republik Indonesia Tahun 1945, Kitab Undang-undang Hukum Pidana (KUHP), UndangUndang Nomor 31 Tahun 1999 tentang Pemberantasan Tindak Pidana Korupsi sebagaimana telah diubah dengan Undang-Undang Nomor 20 Tahun 2001, Undang-Undang Nomor 16 Tahun 2004 tentang Kejaksaan RI, Inpres no. 7 Tahun 2015 tentang Aksi Pencegahan dan Pemberantasan Korupsi Tahun 2015, Keputusan Jaksa Agung RI Nomor: KEP-152/A/JA/10/2015 tentang Pembentukan Tim Pengawal dan Pengamanan Pemerintahan dan Pembangunan Kejaksaan RI, Peraturan Jaksa Agung Nomor: PER-014/A/JA/11/2016 tentang Mekanisme kerja teknis dan administrasi Tim Pengawal dan Pengaman dan Pemerintahan dan Pembangunan.; dan berbagai produk hukum tertulis lainnya yang terkait dengan isu penelitian ini. Bahan hukum sekunder diantaranya berupa buku-buku hukum 
termasuk tesis dan disertasi hukum, jurnal-jurnal hukum, kamus-kamus hukum, komentar-komentar atas putusan pengadilan, hasil penelitian hukum yang relevan, serta sumber lainnya dari internet. Semua bahan hukum primer maupun sekunder yang terkumpul kemudian dikualifikasi dengan menggunakan metode bola salju (snow ball theory) ${ }^{1}$, diinventaris dan diidentifikasi dengan sistem kartu (card system), yang penatalaksanaannya dilakukan dengan secara kritis, logis, dan sistematis untuk kepentingan analisis lebih lanjut. Adapun bentuk analisis yang dilakukan oleh peneliti adalah analisis argumentasi kualitatif.

\section{HASIL PENELITIAN DAN PEMBAHASAN}

\section{A. Tim Pengawal Dan Pengamanan Pemerintahan Dan Pembangunan Daerah (Tp4d) Dalam Menyikapi Proyek Pembangunan Yang Sedang Dikawal Terindikasi Adanya Tindak Pidana Korupsi}

Memperhatikan kegiatan pendampingan yang sedang dilaksanakan oleh TP4D , dikaitkan dengan Presiden Republik Indonesia Nomor 3 Tahun 2016 tentang Percepatan Pelaksanaan Proyek Strategis Nasional yang dalam lampirannya menyebutkan beberapa proyek strategis nasional, permohonan pendampingan yang dimohonkan oleh SKPD pada Pemerintahan Kabupaten Tarakan tidak termasuk dalam proyek strategis nasional. Namun penulis berpendapat Tim Pengawal dan Pengaman Pemerintahan dan Pembangunan Daerah (TP4D) dapat melakukan tugas dan fungsinya melakukan pengawalan dan pengamanan terhadap pembangunan tersebut sebagaimana dengan penjabaran penulis sebelumnya bahwa Tim Pengawal dan Pengaman Pemerintahan dan Pembangunan Daerah (TP4D) Kabupaten/Kota (Kejaksaan Negeri) melakukan pengawalan dan pengamanan terhadap Proyek/kegiatan di lingkungan pemerintah kabupaten/kota. Tentunya dalam suatu kegiatan, akan timbul pihak-pihak yang berpendapat, baik pihak pro maupun pihak kontra.

Keberadaan TP4D mempunyai tujuan dan maksud sebagaimana dengan amanat dari Bapak Joko Widodo selaku Presiden Republik Indonesia, yang tentunya Kejaksaan melalui TP4D dapat turut serta membantu kelancaran pembangunan pusat maupun Daerah, khususnya peranan Kejaksaan yang bertindak secara preventif dalam kegiatan TP4D selain TP4D sendiri

1 Johny Ibrahim, Teori dan Metodologi Penelitian Hukum Normatif, Bayu Media Publishing, Malang, 2006, h. 392. 
terbentuk berdasarkan Amanat Undang undang Nomor 16 Tahun 2004 sesuai dengan Pasal 30 ayat (3) yang mengamanatkan Kejaksaan Republik Indonesia sebagai Lembaga Pemerintah untuk mengamankan Kebijakan Penegak Hukum melalui Pengawalan Kebijakan Anggaran Pembangunan Pemerintah Pusat maupun Daerah, hal ini juga sejalan dengan Inpres Nomor 7 tahun 2015 tentang Aksi Pencegahan dan Pemberantasan Korupsi.

Rapat Kerja Komisi III dengan Jaksa Agung Republik Indonesia tanggal 7 September 2015 menyepakati kesimpulan yaitu untuk menciptakan iklim yang kondusif bagi penyerapan anggaran pembangunan di daerah, Komisi III DPR RI mendukung pembentukan Tim Pengawal dan Pengaman Pemerintahan dan Pembangunan (TP4) di Kejaksaan Agung dan Tim Pengawal dan Pengaman Pemerintahan dan Pembangunan Daerah (TP4D) di Kejaksaan Tinggi dan Kejaksaan Negeri seluruh Indonesia, dengan tetap meningkatkan pengawasan terhadap pelaksanaannya untuk mencegah penyalahgunaan kewenangan di lapangan. ${ }^{2}$

Untuk mengantisipasi animo dan banyaknya permintaan dari stakeholder terkait di, maka perlu segera dipikirkan untuk memperlebar struktur keanggotaan Tim Pengawal dan Pengaman Pemerintahan dan Pembangunan Daerah (TP4D), baik berdasarkan pendekatan masalah (problematic approach) maupun pendekatan fungsi kerja (task function approach). Dilihat dari pendekatan masalah, perlu adanya pembagian tugas dari masing-masing sub tim yang secara khusus melakukan kajian dan pendampingan terhadap pengadaan barang dan jasa, pengadaan tanah, perbankan, keuangan dan asset daerah dan lain sebagainya. Sementara itu berdasarkan pendekatan fungsi kerja, harus dapat dipastikan setiap bagian dari keanggotaan tim tidak terjadi tumpang tindih (overlapping) fungsi maupun pekerjaan yang dilakukannya.

Pada tanggal 1 Maret 2016, Direktur I Bidang Intelijen selaku Ketua TP4 Pusat telah mengeluarkan Surat Keputusan Nomor: KEP001/TP4P/Set/03/2016 tentang Mekanisme Kerja Teknis dan Administrasi Tim Pengawal dan Pengaman Pemerintahan dan Pembangunan Pusat. Namun surat keputusan itu, masih terlalu urnum dan belum merujuk pada hal-hal

2 http://www.tribunnews.com/nasional/2015/09/08/jaksa-agung-klaimdukungan-komisi-iii-dpr-bentuk-tp4 
yang substansial dan teknis. ${ }^{3}$ Apabila dalam perjalanan pengawalan pembangunan Tim TP4D menemukan Tindak Pidana Korupsi, maka tim TP4D menyerahkan pada bidang Tindak Pidana Khusus Kejaksaan RI untuk dilakukan Penyidikan.

Pembentukan tim TP4 bertujuan untuk mengawal dan mengawasi pembangunan di daerah serta mendukung keberhasilan pemerintahan dan pembangunan melalui upaya upaya pencegahan secara preventif dan persuasif. Kejaksaan sesuai ketentuan Undang-undang Nomor 16 Tahun 2004 tentang Kejaksaan memiliki wewenang untuk melakukan penuntutan dan juga dapat bertugas sebagai penyidik untuk perkara tertentu sesuai dengan peraturan perundangan. Dalam penanganan perkara terdakwa tindak pidana korupsi, kejaksaan memiliki wewenang untuk melakukan penyidikan. Dalam pelaksanaannya tim TP4D banyak kemungkinan akan dihadapkan situasi rawan Penyimpangan- penyimpangan dan indikasi terjadinya tindak pidana korupsi terhadap proyek Pembagunan yang sedang dikawal, untuk menghindari hal tersebut sehingga Tim TP4D diharapkan mampu bekerja secara profesional. Selain itu, pembentukan TP4D, juga diharapkan dapat memaksimalkan daya serap anggaran Pembangunan kurang dikarenakan Pemerintah ketakutan untuk melaksanakan pembangunan, sehingga dengan adanya Tim TP4D pemerintah tidak ragu untuk melaksanakan pembangunan.

Dalam sistem peradilan pidana peranan Kejaksaan sangat sentral karena Kejaksaan merupakan lembaga yang menentukan apakah seorang harus diperiksa oleh Pengadilan atau tidak. Jaksa pula yang menentukan apakah seorang akan dijatuhi hukuman atau tidak melalui kualitas surat dakwaan dan tuntutan yang dibuat. Sedemkian pentingnya posisi jaksa bagi proses penegakan hukum sehingga lembaga ini harus diisi oleh orang-orang yang profesional dan memiliki integritas tinggi.

TP4 memiliki tugas dan fungsi yang tertuang Keputusan Jaksa Agung republik Indonesia Nomor : KEP-152/A/JA/10/2015), yaitu :

1. Mengawal, mengamankan dan mendukung keberhasilan jalannya pemerintahan dan pembangunan melalui upaya-upaya pencegahan/preventif dan persuasif baik ditingkat pusat maupun

${ }^{3}$ Asep N. Mulyana, Mekanisme Kerja Teknis dan Administrasi, Gramedia, Jakarta 2014 ., h. 
daerah sesuai wilayah hukum penugasan masing-masing dengan cara-cara :

a. Memberikan penerangan hukum di lingkungan instansi pemerintah, BUMN, BUMD, dan pihak lain terkait materi tentang perencanaan, pelelangan, pelaksanaan pekerjaan, pengawasan pelaksanaan pekerjaan, perijinan, pengadaan barang dan jasa, tertib administrasi dan tertib pengelolaan keuangan negara;

b. Melakukan diskusi atau pembahasan bersama instansi pemerintah, BUMN, BUMD untuk mengidentifikasi permasalahan yang dihadapi dalam penyerapan anggaran dan pelaksanaan pembangunan;

c. Memberikan penerangan dan penyuluhan hukum baik atas insentif TP4 maupun atas permintaan pihak-pihak yang memerlukan tempat dan waktu pelaksanaannya ditetapkan berdasarkan kesepakatan dan sesuai kebutuhan;

d. TP4 dapat melibatkan instansi atau pihak lain yang memiliki kapasitas, kompetensi dan relevan dengan materi penerangan dan penyuluhan hukum yang akan disampikan kepada instansi pemerintah, BUMN, dan BUMD.

2. Dapat memberikan pendampingan hukum dalam setiap program pembangunan dari awal sampai akhir, berupa :

a. Pembahasan hukum dari sisi penerapan regulasi, peraturan perundang-undangan, mekanisme dan prosedur dengan pejabat pengelola anggaran atas permasalahan yang dihadapi dalam hal penyerapan anggaran;

b. Pendapat hukum dalam tahapan perencanaan, pelelangan, pelaksanaan, pengawasan pelaksanaan pekerjaaan dan pengadaan barang dan jasa atas inisiatif TP4 maupun atas permintaan instansi dan pihak-pihak yang memerlukan.

3. Melakukan koordinasi dengan aparat pengawasan intern pemerintah untuk mencegah terjadinya penyimpangan yang berpotensi menghambat, menggagalkan dan menimbulkan kerugian bagi keuangan negara: 
a. Bersama-sama melakukan monitoring dan evaluasi pelaksanaan pekerjaan dan program pembangunan;

b. Melaksanakan penegakan hukum represif ketika ditemukan bukti permulaan yang cukup setelah dilakukan koordinasi dengan aparat pengawasan intern pemerintah tentang telah terjadinya perbuatan melawan hukum, penyalahgunaan kewenangan dan/atau perbuatan lainnya yang berakibat menimbulkan kerugian bagi keuangan negara.

Dalam melaksanakan tugas dan fungsi tim TP4 berpedoman pada mekanisme pelaksanaan yang diatur di dalam Peraturan Jaksa Agung nomor : PER-014/A/JA/11/2016 tentang Mekanisme Kerja Teknis dan Administrasi Tim Pengawal dan Pengaman Pemerintahan dan Pembangunan ( TP4 ).

Terbentuknya TP4/TP4D nantinya berkontribusi menghilangkan atau mengurangi pula tentang keraguan dan ketakutan dari stakeholders atau dalam hal ini pemerintah daerah/ kota beserta perangkatnya dalam menggunakan anggaran alokasi dana untuk pembangunan. Sebab, jika salah mengambil kebijakan, tindakan mereka bisa berujung bui. TP4/TP4D juga sebagai cerminan bahwa Kejaksaan juga bisa untuk berkontribusi pada keberhasilan pembangunan yang pada akhirnya rakyat menjadi sejahtera.

Pengelolaan alokasi dana / anggaran pemerintah yang maksimal dan sesuai dengan koridor hukum harus melibatkan koordinasi dan sinergi yang lebih baik antar lembaga institusi baik itu tingkat pusat maupun daerah. Institusi didaerah seperti pemerintah desa, daerah/ kota, kejaksaan/TP4D, inspektorat, BPK dan BPKP apabila berkoordinasi dan bersinergi terkait pengelolaan dana tersebut akan cukup aktif. Kerjasama yang rutin dan berkualitas tinggi mampu membuat pelaksanaan teknis kelola dana/ anggaran terlebih bagi pelaksana cukup nyaman untuk mengambil keputusan secara lancar, akuntabel dan aman.

Kejaksaan sebagai lembaga penegak hukum telah melakukan langkahlangkah nyata demi mencegah segala potensi-potensi sebagai yang diuraikan diatas. Kejaksaan melalui tugas pokok dan fungsi yang ada telah membentuk struktur organisasi baru yaitu Tim Pengawal dan Pengamanan Pemerintahan dan Pembangunan atau dikenal dengan nama (TP4). TP4 ini berlokasi di pusat (Kejaksaan Agung) dan ditiap-tiap daerah ( Kejaksaan Tinggi dan Kejaksaan Negeri). Kelahiran TP4 mulanya untuk meningkatkan peran 
Kejaksaan dibidang perdata dan tata usaha negara (datun). Selain itu, pembentukan TP4 merupakan salah satu respon Kejaksaan adanya Instruksi Presiden No. 7 Tahun 2015 Tentang Aksi Pencegahan dan Pemberantasan Korupsi tahun 2015.

\section{B. Upaya Kejaksaan Dalam Rangka Menghindari Conflict Of Interest Antara Fungsi Preventif Tim TP4D Dengan Fungsi Penyidikan Dan Penuntutan Di Bidang Tindak Pidana Korupsi}

Sebelum melakukan pengawalan dan pengamanan, Tim Pengawal dan Pengaman Pemerintahan dan Pembangunan Daerah (TP4D) perlu menetapkan kriteria dan mekanisme kerja yang jelas dimana pihak yang meminta pendampingan tidak sedang dalam proses hukum. Hal ini dimaksudkan agar tidak terjadi conflict of interest dengan tugas dan wewenang kejaksaan pada umumnya.

Persoalan otonomi daerah dengan polemik Korupsi, semakin menempatkan kapabelitas aparat penegak hukum, khususnya kejaksaan Agung RI untuk memerangi terhadap penyimpangan atas pengelolaan keuangan di daerah, dengan peningkatan kualitas dan SDM kejaksaan melalui peran yakni melaksanakan fungsi dan kewenangan sesuai dengan ketentuan perundang-undangan. Kejaksaan Republik Indonesia adalah lembaga negara yang melaksanakan kekuasaan negara, khususnya di bidang penuntutan yang melaksanakan fungsi, tugas dan wewenangnya secara merdeka, terlepas dari pengaruh kekuasaan pemerintah dan pengaruh kekuasaan lainnya, sebagai badan yang berwenang dalam penegakan hukum dan keadilan. Namun demikian, dalam melaksanakan kewenangannya terdapat beberapa hambatan yang dihadapi oleh kejaksaan termasuk oleh Tim Pengawal dan Pengaman Pemerintahan dan Pembangunan.

Faktor Substansi Hukum, Pelaksanaan Tugas Tim Pengawal, Pengaman Pemerintahan dan Pembangunan Daerah (TP4D) pada adalah adanya anggapan bahwa pembentukan Tim Pengawal, Pengaman Pemerintahan dan Pembangunan Daerah (TP4D) pada dianggap tidak memiliki kekuatan hukum karena sifatnya hanya keputusan dan instruksi untuk internal Kejaksaan saja.

Berkaitan dengan hal tersebut, jika dibandingkan dengan lembaga negara lainnya yang juga berwenang melakukan pencegahan tindak pidana korupsi, maka kedudukan TP4D lebih rendah dibandingkan kedudukan 
lembaga negara lainnya, seperti Badan Pemeriksa Keuangan (BPK), Inspektorat Jenderal (Itjen), Komisi Pemberantasan Korupsi (KPK), Badan Pengawas Keuangan dan Pembangunan (BPKP), dan Inspektorat Daerah (Itda). Dalam hal terjadi benturan kewenangan, maka kedudukan TP4D menjadi organ yang bukan superior sehingga kewenangan pengawasan program pemerintah menjadi kurang optimal.

Dari aspek struktur hukum, faktor kelembagaan TP4D yang diposisikan pada lembaga yang berada di bawah naungan bidang intelijen kejaksaan berakibat pada hadirnya potensi konflik kepentingan dengan fungsi penegakan hukum. Hal ini dikarenakan bentuk pengawasan yang dilakukan merupakan pengawasan terhadap kegiatan yang merupakan pencegahan tindak pidana korupsi. Sementara dalam organ kejaksaan sendiri, terdapat bidang yang membawahi tindak pidana korupsi. Hal ini dapat mengurangi efektifitas penanganan tindak pidana korupsi pada pembangunan di daerah. Selain itu, faktor yang terberat adalah terkait dengan SDM dimana dalam melaksanakan fungsi sebagai bagian dari TP4D, seorang jaksa juga memiliki tugas pokok yang harus dilaksanakan. Hal ini berakibat pada beban kerja seorang jaksa yang bertambah.

Untuk menghidari terjadinya conflict interest, maka Kejaksaan diharuskan untuk:

1. Menghindari adanya hubungan afiliasi, yaitu hubungan yang dimiliki oleh seseorang pejabat TP4D dengan pihak tertentu yang berkaitan dengan pekerjaan proyek pembangunan.

2. Menghindari Gratifikasi, yaitu pemberian dalam arti luas yang meliputi pemberian uang, barang, rabat, komisi, pinjaman tanpa bunga, tiket perjalanan, fasilitas penginapan, perjalanan wisata, pengobatan cuma-cuma, dan fasilitas lainnya.

3. Menghidari Kepentingan pribadi (vested Interest), yaitu keinginan/kebutuhan seorang penyelenggara negara mengenai suatu hal yang bersifat pribadi.

Dalam pandangan penulis, kedudukan TP4D yang diposisikan pada bidang intelijen memang dapat berpotensi pada konflik kepentingan di tubuh kejaksaan. Hal ini akan berakibat pada kurang efektifnya pencegahan tindak pidana korupsi di daerah. Ada baiknya, TP4D di isi oleh jaksa yang juga merupakan bagian dari bidang tindak pidana korupsi, atau bahkan perlu 
diupayakan pembentukan bidang khusus yang berkaitan dengan TP4D. Hal ini dimaksudkan agar jaksa yang ditugasi pada TP4D dapat melakukan tugas dengan optimal serta menghindari adanya konflik kepentingan dalam pelaksanaan tugas di lapangan.

Faktor penghambat lainnya yang berkaitan dengan struktur hukum adalah Anggota Tim Pengawal, Pengaman Pemerintahan dan Pembangunan Daerah (TP4D) yang dibentuk belum seluruhnya mendapatkan pelatihan berkenaan dengan tata cara dan mekanisme proses pendampingan terhadap Satuan Kerja Perangkat Daerah (SKPD). Walaupun belum seluruhnya anggota Tim Pengawal, Pengaman Pemerintahan dan Pembangunan Daerah (TP4D) dari mendapatkan pelatihan berkenaan dengan tata cara dan mekanisme proses pendampingan, akan tetapi secara garis besar tujuan dibentuknya Tim Pengawal, Pengaman Pemerintahan dan Pembangunan Daerah (TP4D) ini untuk melakukan pengawasan terhadap proses pembangunan di daerah yang selama ini terindikasi adanya penyimpangan dalam penggunaan anggaran keuangan daerah.

Dari aspek kultur hukum, hambatan yang dihadapi dalah adanya pandangan/anggapan dari pejabat-pejabat daerah yang ada di instansi Pemerintah bahwa Tim Pengawal, Pengaman Pemerintahan dan Pembangunan Daerah (TP4D) hanya mencari-cari kesalahan dan ingin ikut campur dalam pelaksanaan kegiatan pembangunan daerah. Kondisi ini berimplikasi pada kurang transparannya pemerintah daerah terhadap TP4D khususnya dalam penggunaan anggaran pembangunan.

Dalam pandangan penulis, sebenarnya pejabat daerah dari Satuan Kerja Perangkat Daerah (SKPD) Pemerintah tidak perlu takut dengan dibentuknya Tim Pengawal, Pengaman Pemerintahan dan Pembangunan Daerah (TP4D) oleh karena TP4D justru membantu Satuan Kerja Perangkat Daerah (SKPD) Pemerintah dalam bentuk pendampingan agar pelaksanaan pembangunan tidak mengalami penyelewengan atau penyimpangan dalam penggunaan keuangan daerah yang bisa dikualifisir sebagai tindak pidana korupsi.

Atas dasar Instruksi Presiden Nomor 7 Tahun 2015 tentang Aksi Pencegahan dan Pemberantasan Korupsi Tahun 2015, maka Jaksa Agung menerbitkan Keputusan Jaksa Agung Republik Indonesia Nomor: KEP152/A/JA/10/2015 tentang Pembentukan Tim Pengawal, Pengaman Pemerintahan dan Pembangunan (TP4) dan Instruksi Jaksa Agung Republik Indonesia Nomor: INS-001/A/JA/10/2015 tentang Pembentukan dan 
Pelaksanaan Tugas Tim Pengawal, Pengaman Pemerintahan dan Pembangunan Pusat (TP4P) dan Daerah (TP4D). Pembentukan Tim Pengawal, Pengaman Pemerintahan dan Pembangunan Daerah (TP4D) ini bukan tanpa alasan, di mana pada tahun 2015 lalu penyerapan anggaran yang dialami oleh pemerintah pusat maupun daerah sangat rendah. Hal ini dikarenakan banyak pejabat daerah yang takut dipidanakan apabila salah atau menyimpang dalam menggunakan anggaran tersebut.

Jika dilihat dari tugas dan kewenangan Tim Pengawal, Pengaman Pemerintahan dan Pembangunan Daerah (TP4D) tersebut di atas, maka dapat dikatakan bahwa tugas dan kewenangan Tim Pengawal, Pengaman Pemerintahan dan Pembangunan Daerah (TP4D) hanya sebatas melakukan pengawalan dan pengamanan jalannya pemerintahan dan pembangunan melalui upaya-upaya preventif dan melakukan penerangan serta penyuluhan hukum dalam setiap tahapan program pembangunan dari awal sampai akhir. Sedangkan untuk tugas pengawasan, monitoring dan evaluasi pelaksanaan pekerjaan dan program pembangunan daerah harus melakukan koordinasi dengan Badan Pengawas Keuangan dan Pembangunan (BPKP) untuk mencegah terjadinya penyimpangan yang berpotensi menghambat, menggagalkan dan menimbulkan kerugian bagi keuangan negara.

Selain itu dalam pengawalan pembangunan TP4D harus membatasi bahwa pengawalan pembangunan Tim TP4D hanya membatasi pada hal-hal yuridis dan tidak berkaitan dengan teknis atau fisik pekerjaan di luar keahlian Tim TP4D.

\section{KESIMPULAN DAN SARAN}

Berdasarkan batasan rumusan masalah penelitian maka penulis menetapkan beberapa pokok kesimpulan sebagai berikut:

1. Pelaksanaan Kewenangan oleh Tim pengawal dan pengamanan pemerintahan dan pembangunan daerah (TP4D) dalam menyikapi Proyek Pembangunan yang sedang dikawal terindikasi adanya tindak Pidana Korupsi adalah melalui Pencegahan preventif dan persuasif yang dilakukan dengan cara memberikan penerangan hukum di lingkungan pemerintah Daerah tentang perencanan, pelelangan, pelaksanaan pekerjaan, pengawasan pelaksanaan pekerjaan, perizinan, pengadaan barang dan jasa, tertib administrasi dan tertib pengelolaan keuangan Negara, melakukan diskusi atau pembahsan bersama dengan Pemerintah Daerah/ 
Dinas terkait untuk mengidentifikasi permasalahan yang dihadapi dalam penyerapan anggaran dan pelaksanaan pembangunan. Pendampingan Hukum dilakukan dengan cara melakukan pembahasan hukum dari sisi regulasi, peraturan perundang-undangan, mekanisme dan prosedur dengan pejabat pengelola anggaran atas permasalahan yang dihadapi dalm hal penyerapan anggaran; memeberikan pendapat hukum dalam tahapan perencanaan, pelelangan, pelaksanaan pekerjaan, pengawasan pelaksanaan pekerjaan atas inisiatif TP4D maupun dari pihak terkait sehingga pendapat hukum tersebut dapat dijadikan sebagai rekomendasi bagi pemohon. Selain itu, dilakukan Koordinasi dengan Aparat Pengawasan Interen Pemerintah (APIP) dan atau instansi terkait yang dilakukan dengan maksud untuk mencegah terjadinya penyimpangan yang berpotensi menghambat, menggagalkan dan menimbulkan kerugian bagi keuangan Negara sehingga dilakukan koordinasi dengan aparat intern pemerintah (APIP) mauun instansi terkait lainnya. Tindakan lainnya adalah melakukan monitoring dan evaluasi yang dilakukan bersama-sama dengan pemohon yang dilakukan secara berkasal sesuai dengan tahapan kegiatan atau pekerjaan pembangunan. Penegakan hukum represif dilakukan manakala ditemukan bukti permulaan yang cukup setelah dilakukan koordinasi dengan aparat terkait tentang telah terjadinya perbuatan melawan hukum, penyalahgunaan kewenanagan maupun perbuatan lainnya yang berakibat menimbulkan kerugian bagi keuangan Negara. Apabila dalam perjalanan pengawalan pembangunan Tim TP4D menemukan Tindak Pidana Korupsi, maka tim TP4D menyerahkan pada bidang Tindak Pidana Khusus Kejaksaan RI untuk dilakukan Penyidikan.

2. Upaya Kejaksaan dalam rangka menghindari Conflict of interest antara fungsi preventif tim TP4D dengan fungsi Penyidikan dan Penuntutan di bidang Tindak pidana korupsi adalah dengan cara menghidari adanya hubungan afiliasi, yaitu hubungan yang dimiliki oleh seseorang pejabat TP4D dengan pihak tertentu yang berkaitan dengan pekerjaan proyek pembangunan, menghindari Gratifikasi, yaitu pemberian dalam arti luas yang meliputi pemberian uang, barang, rabat, komisi, pinjaman tanpa bunga, tiket perjalanan, fasilitas penginapan, perjalanan wisata, pengobatan cuma-cuma, dan fasilitas lainnya, serta menghidari Kepentingan pribadi (vested Interest), yaitu keinginan/kebutuhan seorang 
penyelenggara negara mengenai suatu hal yang bersifat pribadi. Selain itu dalam pengawalan pembangunan TP4D harus membatasi bahwa pengawalan pembangunan Tim TP4D hanya membatasi pada hal-hal yuridis dan tidak berkaitan dengan teknis atau fisik pekerjaan di luar keahlian Tim TP4D.

Berpijak dari rumusan pokok kesimpulan penelitian yang dipaparkan penulis, maka berikut ini penulis memberikan beberapa saran dan rekomendasi:

1. Agar Kejaksaan RI membuat SOP (Standar Operasional Prosedur) maupun peraturan-peraturan yang lebih lengkap terkait Tim Pengawal dan Pengaman Pemerintah dan Pembangunan Daerah sebagai landasan atau pegangan Tim TP4D, karena TP4D bukan hanya Kejaksaan RI tetapi juga melibatkan Kepolisian RI dalam melaksanakan agar tidak terjadi Conflict of interest dengan tugas Kejaksaan RI yang lain .

2. Agar Kejaksaan RI melibatkan instansi terkait yang berkaitan dengan pencegahan tindak pidana korupsi di daerah, seperti LKPP, BPKP dan Inspektorat Daerah untuk mewujudkan sinergitas antar lembaga terkait serta untuk semakin memperlancar Tugas Pokok dan Fungsi TP4D. 


\section{REFERENSI}

Arief, Barda Nawawi, Kebijakan Formulasi Ketentuan Pidana, Dalam Peraturan Perundang-undangan, Semarang: Pustaka Magister, 2012.

Djamali, Abdoel, Pengantar hukum Indonesia, Jakarta, Raja Grafindo, Jakarta, 2007.

Endro P, Didik, Hukum Pidana, Untaian Pemikiran, Airlangga University Press, Surabaya, 2019.

Gosita, Arif, Hak dan Kewajiban Korban, Gramedia, Jakarta. 2012

Hadjon, Philipus M \& Tatiek S Djatmika, Argumentasi Hukum, Gadjahmada University Press, Jogjakarta, 2008. , Perlindungan Hukum Bagi Rakyat Indonesia. Bina Ilmu,

Surabaya, 1987.

Hanafiah, M. Jusuf, Amri Amir, Etika Kedokteran dan Hukum Kesehatan, Kedokteran EGC. Jakarta, 2014

Harahap, M. Yahya, Ruang Lingkup Permasalahan Eksekusi, Gramedia, Jakarta, 1991.

Hasbullah, M. Afif, Politik Hukum Ratifikasi Konvensi HAM di Indonesia Upaya Mewujudkan Masyarakat yang Demokratis, Pustaka Pelajar, Yogyakarta, 2005.

Ibrahim, Johny, Teori dan Metodologi Penelitian Hukum Normatif, Bayu Media Publishing, Malang, 2006.

Ishaq, Dasar-dasar Ilmu Hukum. Sinar Grafika. 2009.

Lamintang, P.A.F, Dasar-Dasar Hukum Pidana Indonesia. Citra Aditya Bakti, Bandung, 1990.

Marzuki, Peter Mahmud, Penelitian Hukum, Prenada Media Grup, Jakarta, 2007.

Pengantar Ilmu Hukum, Prenadya Kencana, Jakarta,

2017.

Pengantar Ilmu Hukum. Kencana. Jakarta. 2008.

MD, Mahmud, Membangun Politik Hukum, Menegakkan Konstitusi, Raja Grafindo Persada Persada, Jakarta, 2010.

Mertokusumo, Sudikno, Mengenal Hukum Suatu Pengantar, Liberty, Jogjakarta, 2005.

Moeljatno, Asas-Asas Hukum Pidana. Rineka Cipta, Jakarta, 2015. Muhammad Yamin,

Tindak Pidana Khusus, Pustaka Setia, Bandung, 2012. Nawawi, Barda,Muladi , Teori-teori dan Kebijakan Pidana, Alumni, Bandung, 1984.

Nawawi, Barda, Bunga Rampai Kebijakan Hukum Pidana, Kencana, Jakarta, 2010. Bunga Rampai Kebijakan Hukum Pidana, Perkembangan Penyusunan Konsep KUHP Baru, Kencana Prenada Media Group, Jakarta, 2011 
Raharjo, Satjipto, Penyelenggaraan Keadilan dalam Masyarakat yang sedang berubah. Jurnal Masalah Hukum. 2010.

Poernomo, Bambang, Asas-Asas Hukum Pidana, : Ghalita Indonesia, Jakarta 1992.

Prasetyo, Teguh, Hukum Pidana, Raja Grafindo Persada, Jakarta, 2010.

Prodjodikoro, Wirjono, Asas-Asas Hukum Pidana di Indonesia. Rineka Cipta, Jakarta, 2015.

Setiono, Rule of law (supremasi Hukum). Magister Ilmu Hukum Program Pascasarjana Universitas 11 Maret. Surakarta. 2004.

Soeroso, R., Pengantar Ilmu Hukum, Sinar Grafika, Jakarta, 2006.

Soekidjo Notoatmodjo, Etika dan Hukum Kesehatan, Rineka Cipta, 2010.

Sungguh, As'ad, Kode Etik Profesi tentang Kesehatan, Jakarta Timur, 2014.

Sudarto, Hukum dan Hukum Pidana, Bandung: Alumni, 1981.

Sudarto, Hukum Pidana dan Perkembangan Masyarakat, Bandung: Sinar Baru.1983.

Sunarso, Siswanto, Filsafat Hukum Pidana Konsep, Dimensi, dan Aplikasi, Raja Grafindo Persada, Jakarta, 2015.

Syamsuddin, Aziz, Tindak Pidana Khusus: Sinar Grafika, Jakarta, 2011.

Syarifin, Pipin, Pengantar Ilmu Hukum, Pustaka Setia, Bandung, 2009. 